\title{
A comparative study on the health and well- being of adolescent immigrants in Spain and Portugal
}

\section{Saúde e bem-estar nos adolescentes imigrantes em Espanha e Portugal: um estudo comparativo}

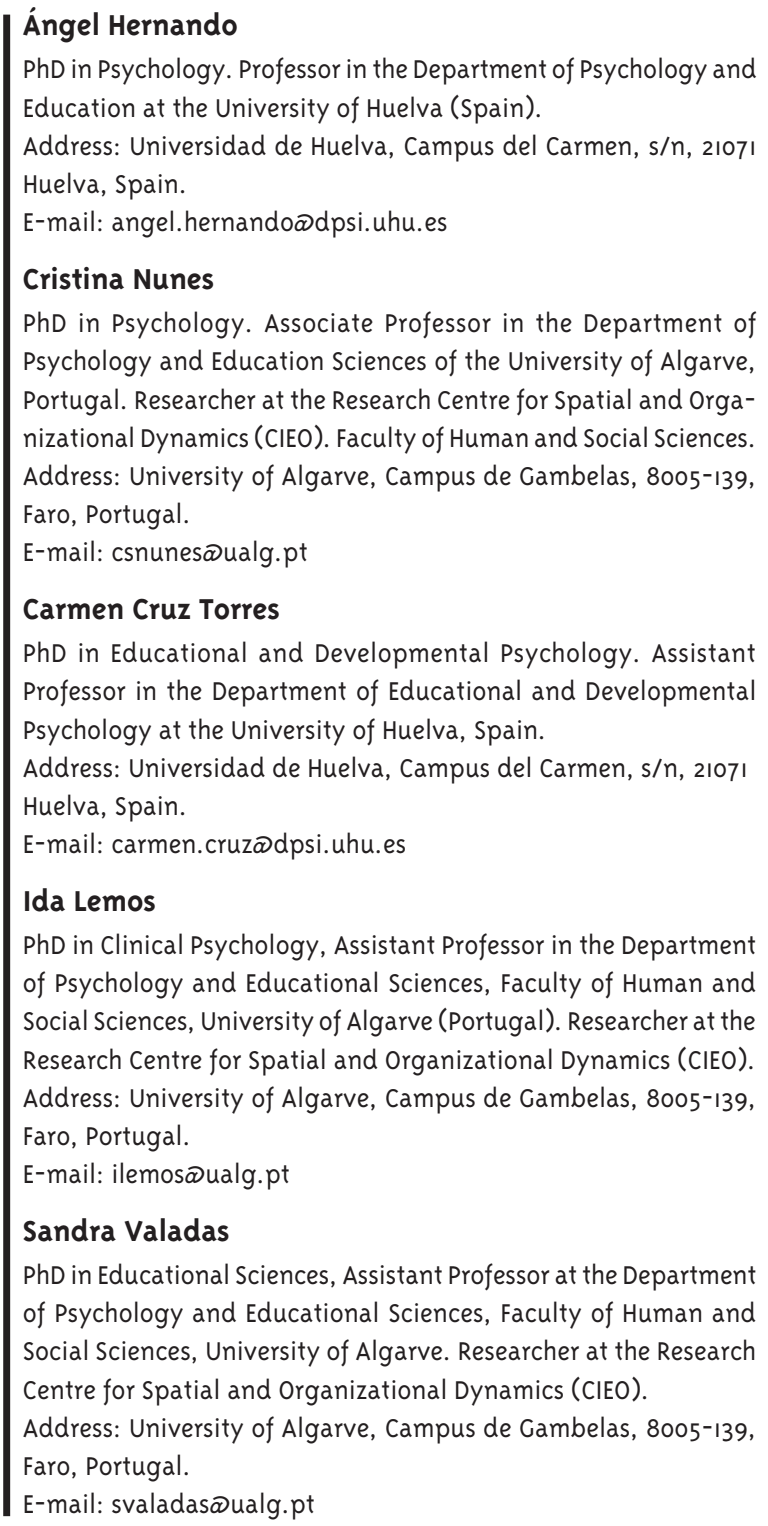

\section{Cristina Nunes}

PhD in Psychology. Associate Professor in the Department of Psychology and Education Sciences of the University of Algarve, Portugal. Researcher at the Research Centre for Spatial and Organizational Dynamics (CIEO). Faculty of Human and Social Sciences. Address: University of Algarve, Campus de Gambelas, 8005-139, Faro, Portugal.

E-mail: csnunesळualg.pt

\section{Carmen Cruz Torres}

PhD in Educational and Developmental Psychology. Assistant Professor in the Department of Educational and Developmental Psychology at the University of Huelva, Spain.

Address: Universidad de Huelva, Campus del Carmen, s/n, 21071 Huelva, Spain.

E-mail: carmen.cruzœdpsi.uhu.es

\section{Ida Lemos}

PhD in Clinical Psychology, Assistant Professor in the Department of Psychology and Educational Sciences, Faculty of Human and Social Sciences, University of Algarve (Portugal). Researcher at the Research Centre for Spatial and Organizational Dynamics (CIEO). Address: University of Algarve, Campus de Gambelas, 8005-139, Faro, Portugal.

E-mail: ilemosळualg.pt

\section{Sandra Valadas}

PhD in Educational Sciences, Assistant Professor at the Department of Psychology and Educational Sciences, Faculty of Human and Social Sciences, University of Algarve. Researcher at the Research Centre for Spatial and Organizational Dynamics (CIEO).

Address: University of Algarve, Campus de Gambelas, 8005-139, Faro, Portugal.

E-mail: svaladasळualg.pt

\section{Abstract}

The terms on which the integration of new generations of immigrants into Portuguese and Spanish societies happens will have a decisive influence in the future of both countries. Therefore, promoting their health, well-being, and psychosocial adaptation is a matter of strategic interest. This paper analyses psychosocial factors associated with well-being and psychological adjustment on a sample of 108 adolescents ( 55 males and 53 females), children of immigrants from Huelva (Spain) and Algarve (Portugal), aged between 10 and 17 years. Adolescents were assessed for demographic characteristics and perceived well-being. We used the "KIDSCREEN-5", a self-report questionnaire that yields detailed profile information for children aged 8 to 18 years for the following ten dimensions: Physical well-being, Psychological well-being, Moods and emotions, Self-perception, Autonomy, Parental relationships and home life, Financial resources, Social support and peers, School environment, and Social acceptance (Bullying). Overall, significant differences were found between the Spanish and Portuguese samples on physical well-being, psychological well-being, mood, financial resources and social acceptance (bullying). Boys perceived themselves as having a better physical well-being than girls. Mothers' educational level was associated with psychological well-being and mood. Also, results suggested that residence location and other socio-demographical variables were not associated with the adolescents' well-being and psychological adjustment.

Keywords: Immigration; Adolescence; Well-being; Psychological Adjustment; Health. 


\section{Resumo}

O modo como as novas gerações de imigrantes se irão integrar nas sociedades espanhola e portuguesa terá uma influência decisiva no futuro de ambos os países. Promover a sua saúde, bem-estar e adaptação psicológica é por isso uma questão de interesse estratégico. Este trabalho analisa os factores em jogo no bem-estar e adaptação psicológica numa amostra de 108 adolescentes (55 rapazes e 53 raparigas), filhos de imigrantes em Huelva (Espanha) e no Algarve (Portugal), com idades compreendidas entre os 10 e os 17 anos. Foram recolhidos dados sobre as características sócio-demográficas e o bem-estar percebido dos adolescentes. Utilizámos o KIDSCREEN-52, questionário que avalia a percepção dos adolescentes sobre a sua saúde e bem-estar em dez dimensões: Bem-estar físico, Bem-estar psicológico, Estado de ânimo, Auto-percepção, Autonomia, Relações com os pais e vida familiar, Recursos económicos, Apoio social e dos pares, Ambiente escolar e Aceitação social (Bullying-rejeição). Entre os principais resultados destacamos as diferenças significativas entre as pontuações obtidas na amostra de Espanha e Portugal no Bem-estar físico, Bem-estar psicológico, Estado de ânimo, Recursos económicos e Aceitação social (Bullying-rejeição) respectivamente. Os rapazes percebem-se com melhor bem-estar físico. 0 nível de escolaridade da mãe está relacionado com o bem-estar psicológico e o estado de ânimo. Não encontrámos efeitos do tempo de residência nem de outras variáveis sociodemográficas estudadas no bem-estar e adaptação psicológica dos adolescentes. Palavras-chave: Imigração; Adolescência; Bem-estar; Adaptação psicológica; Saúde.
In the last decades, policies in Portugal and Spain have shifted from sponsoring mass emigration to hosting immigrants. The integration of new generations of immigrants in Portuguese and Spanish societies will have a significant influence in the future of these countries. Namely in their future economic prosperity, the structure and financing of their social institutions, and the civic participation of their citizenry will depend, among others, on the health status and adjustment of children in immigrant families. In consequence, to promote their health, well-being, and psychosocial adaptation is a matter of strategic interest for both countries.

The development of immigrant adolescents occurs in a context of acculturation. Depending on its characteristics, this process of acculturation can increment the development of their identity, facilitate relations with peers, and encourage the transition to a professional career or to higher education (Almagren et al., 2009; Berry, 1980; Fry, 2007; Fuligni and Hardway, 2004; Johnson, 2007). Also, adolescent acculturation can affect engagement on risk behaviour, increasing substance abuse and sexual risk (Bermúdez et al., 2010; Brindis et al., 1995; Castro et al., 2009).

Based on the relative strengths of identification with one's own ethnic group and the mainstream society, Berry (1980) described four modes of acculturation: Integrated individuals have strong identification with both their own ethnic group and the mainstream society; assimilated individuals have strong identification with the mainstream society, but weak ties with their own ethnic group; separated individuals have strong identification with their own ethnic group, but weak attach with the mainstream society; and, marginalized individuals have weak identification with both groups.

Several studies (Mendoza et al., 2007; Phinney and Ong, 2007) suggest that in order to promote the psychological well-being of immigrant adolescents it is necessary to help them to develop a strong feeling of identity and involvement with the members of the society they live in and, at the same time, maintain significant ties with their ethnic or cultural group of origin.

Furthermore, the process of transition involved in immigration has been described as a potentially positive experience, an opportunity for personal 
growth and for self-development. For instance, results from a recent research conducted by Berry et al. (2006) with immigrant adolescents in 13 countries, suggested that immigrant youth were just as well adapted as their national peers and, on the whole, even reported slightly fewer psychological problems, better school adjustment and fewer behavioral problems when compared to non-immigrant adolescents.

Results from a study developed in Galicia (north of Spain) by Marsiglia et al. (2008) indicated that immigrant youth with Latin American origins do appear to benefit of a certain level of protection from substance use, when compared to Spanish native youth with similar developmental and academic characteristics.

In Portugal, a study developed by Neto (2009) with immigrant and native adolescents showed that adolescents from immigrant families reported fewer mental health problems than their native Portuguese counterparts.

However, immigration is also a potentially risk-laden, negative experience that can endanger one's identity (Pussetti, 2010; Vedder and Van Geel, 2012). Stress related with immigration is expressed by the difficulties the individual faces in the new country, such as economic hardship, language and cultural gaps, social discrimination, and a loss of social, familiar and support networks. Quite consistently, adverse impacts of immigration were found across a variety of domains, such as, mental health and psychological well-being (Ryan et al., 2006; Vieno et al., 2009), developmental processes (Berry et al., 2006; Walsh et al., 2005), educational achievement (Fuligni, 2011; Fuligni et al., 2005), and family and social relationships (Kwak, 2003; Phinney et al., 200o) among others.

Nevertheless, there is substantial variety of resources and needs among immigrants from different countries and on the social status of origin. The individual and family characteristics, purposes for immigrating, and the social context that families encounter when they arrive, play an important part in the origin of these differences (Feliciano, 2005; Hernandez et al., 2009; Sabatier, 2008).

In this sense, the main goal of the present study is to identify and analyse psychosocial factors that may influence the well-being and psychological adjustment of immigrant children.

\section{Method}

\section{Sample}

The sample consisted of 108 adolescents ( 55 boys and 53 girls), aged between 10 and 17 years ( $M=13.77$; $\mathrm{SD}=1.68$ ), from public schools in the Algarve (Portugal) and Huelva (Spain) regions. Students were enrolled in $1^{\text {st }}, 2^{\text {nd }}$ and $3^{\text {rd }}$ grades of secondary school in Spain, and in $5^{\text {th }}$ to $9 \mathrm{t}^{\mathrm{h}}$ school years in Portugal $\left(2^{\text {nd }}\right.$ and $3^{\text {th }}$ cycles of study in both countries). Sixty nine percent of the immigrant children did not obtain an academic equivalence when arriving at Portugal or Spain (i.e., the students were not integrated in the same course grade that he or she had attended in the country of origin), whereas $31 \%$ of the students obtained school equivalence.

About $80 \%$ of the students lived in a city, and $20 \%$ were residents in a rural area. Regarding the country of origin, a great diversity was found: the participants were natives from eighteen countries, mostly Morocco, Ecuador, Moldova, Romania, Ukraine and Brazil. The dominant nationalities were grouped into the following categories: Eastern Europe $(n=60)$, Africa $(n=15)$, Spain $(n=13)$, Brazil $(n=12)$ and, other South America countries ( $n=5)$.

Concerning the mother language of the adolescents, it was very diverse, with predominance of Portuguese, Spanish, Moldavian, Arabic, Ukrainian, Romanian and Creole. Eighty seven percent of the adolescents spoke exclusively the mother tongue at home, whereas $10 \%$ communicated with the family both in their mother tongue and in the language of the host country.

About $76 \%$ of the adolescents live with both parents and siblings, whereas $15 \%$ live in a monoparental family. Parents had an average of 8.5 years residing in the host country, and adolescents an average of 4.6 years. $69 \%$ of the students were living in apartments and $31 \%$ in houses. Furthermore, $13 \%$ of mothers and fathers had no education, $45 \%$ of mothers and $38 \%$ of fathers had completed basic education and $24 \%$ of mothers and $30 \%$ of fathers had completed the secondary education. Finally, $17 \%$ of mothers and $16 \%$ of fathers had completed a higher education degree. 


\section{Instruments}

The participants in our sample completed the KIDSCREEN-52 (The European Kidscreen Groupe, 2006), a questionnaire that assesses the perceptions of adolescents about their health and wellbeing, developed simultaneously in representative samples of several European countries. The Portuguese version was validated by Matos et al. (2006) and the Spanish version by Pantzer et al. (2006). The questionnaire can be applied individually or collectively to adolescents aged between 8 and 18. It consists of 52 items to be rated on a scale from 1 (no/never) to 5 (very much/always) and grouped according to the following dimensions.

1. Physical Wellbeing: It refers to physical activity levels, energy and fitness. Includes five items (e.g. "Did you feel well and fit?"). Internal consistency, measured by Cronbach alpha $(\alpha)$, equals o.8o.

2. Psychological Wellbeing: This dimension evaluates the psychological well-being, including positive emotions and life satisfaction. It consists of 6 items (e.g. "Did you feel satisfied with life?") ( $\alpha=0.89$ ).

3. Mood: This scale includes seven items relating negative experiences, depressive mood and feelings of distress (for example: "Did you feel sad?") $(\alpha=0.86)$.

4. Self-perception: Evaluates the subject's perception of self, physical appearance and satisfaction related to those. Includes five items (e.g., "Where you concerned about your appearance?”) ( $\alpha=0.79$ ).

5. Autonomy: includes five items that inquire about opportunities to dispose of their leisure time (e.g., "Were you able to choose what to do in your spare time?”) ( $\alpha=0.84)$.

6. Relations with parents and family life: This dimension examines the relationship with parents and the family atmosphere. It consists of six items (e.g. "Do your parents understand you? Are you able to talk to your parents whenever you want?")( $\alpha=0.89)$.

7. Financial Resources: Assesses the perception of the adolescents family financial capacity. It includes three items (e.g., "Have you had enough money to do what your friends do?") ( $\alpha=0.89$ ).
8. Social support and support from peers: This dimension reflects the nature of the subject's social relations with others. It consists of six items (e.g.," Have you been able to talk about everything with your friends?") ( $\alpha=0.85$ ).

9. School Environment: This dimension includes six items that assess the perception of the boy or girl on their aptitude for learning, concentration and feelings about school (for example "You have done well in school?") ( $\alpha=0.87)$.

10. Social Acceptance (Bullying-rejection): Assesses feelings of rejection by peers. It includes three items (e.g. "Have you been bullied or threatened by other girls or boys") ( $\alpha=0.77)$.

The alpha values obtained on the KIDSCREEN 52 for the sample studied indicated satisfactory levels of internal consistency ( $\alpha=82)$.

\section{Procedure}

School boards were contacted and agreed to participate. Informed consent of both parents was required through a letter sent home through the children. Both parents and children were informed that participation was voluntary and that non-participation would not adversely affect them. At the time of the data collection, at least two investigators were present in the classroom in order to supervise and to answer any additional questions.

\section{Results}

Results of independent samples $t$ test procedures (Table 1) suggest significant differences in the mean values of the scores obtained in the KIDS52 factors, depending on the country of residence (Spain - Portugal).

We can observe that there are significant differences between Spanish and Portuguese adolescents for factors 1, 2, 3, 7 and 10, relating to Physical Well-being, Psychological Well-being, Mood, Financial Resources and Social Acceptance (Bullying-rejection), respectively.

When comparing means, differences were found according to nationality. In the first and second factors the average scores observed in the Spanish 
Table I- Differences in the KIDSCREEN-52 factors according to the country

\begin{tabular}{|c|c|c|c|c|}
\hline & Portugal & Spain & $F$ & $p$ \\
\hline FI. Physical Well-being & 2.57 & 3.61 & 21.14 & $<.001$ \\
\hline F2. Psychological Well-being & 3.05 & 3.95 & 12.66 & $<.001$ \\
\hline F3. Mood & 3.18 & 2.15 & 10.06 & $<.001$ \\
\hline $\mathrm{F}_{4}$. Self-perception & 3.01 & 3.18 & 0.42 & .139 \\
\hline F5. Autonomy & 3.98 & 3.89 & 4.46 & .566 \\
\hline F6. Relations with parents and family life & 3.97 & 3.9 & 0.07 & .640 \\
\hline F7. Financial Resources & 3.81 & 3.4 & 1.27 & .045 \\
\hline F8. Social support and support from peers. & 4.09 & 3.94 & 0.16 & .313 \\
\hline F9. School Environment & $3 \cdot 7$ & 3.79 & $7 \cdot 57$ & .577 \\
\hline Fio. Social Acceptance & 1.7 & 3.14 & 4.56 & .009 \\
\hline
\end{tabular}

sample are higher than those obtained in the Portuguese sample, suggesting that the physical and psychological well-being of the Spanish sample is higher when compared with the Portuguese immigrant adolescents; in particular, the results showed significant differences between groups with respect to Factor 1 "Physical well-being" [F (1.108) = 21,145, $p=0.000]$. As shown in Table 1, adolescents who lived in Spain scored significantly higher on this factor, which seems to reflect their levels of physical activity, energy and fitness, when compared to the adolescents living in Portugal.

With respect to Factor 2 "Psychological well-being", the analysis suggests significant differences between the two groups $[F(1,108)=12,665, p=0.000]$. In fact, adolescents who lived in Spain also scored significantly higher on this dimension, when compared to the adolescents living in Portugal, which seems to be reflected in the Spanish psychological well-being, including positive emotions and satisfaction with life. On the opposite, the Portuguese sample scored significantly higher than the Spanish sample in Factor 3 "Mood" $[\mathrm{F}(1,108)=10,062, \mathrm{p}=.000]$, expressing, therefore, a less positive mood, with a higher report of negative events, depressive mood and stress.

Similarly, the median score obtained by the Portuguese adolescents in Factor 7 "Financial resources", which assesses the perception of the families' economic ability, was higher than the average score obtained by the Spanish immigrant adolescents. The differences reported in this factor were statistically significant between the two groups $[\mathrm{F}(1,108)=1247$, $p=0.045]$. These results suggest that the perception of financial capacity of Portuguese adolescents is more positive than the financial ability reported by the Spanish sample.

Finally, significant differences were found in the dimension 10 related to "Social acceptance", which refers to feelings of rejection by peers. As shown in Table 1, significant differences were found between the two groups in the Social Acceptance factor [F $(1,108)=4762, p=0.009]$ : the adolescents living in Spain, scoring significantly higher than those living in Portugal, suggesting that the Spanish report more feelings of rejection by peers and others, when compared to their Portuguese peers.

In Table 2 are indicated the results of the comparison between the average scores obtained in each of the factors of the KIDSCREEN-52 according to gender. Results suggested significant differences between groups in Physical well-being, with boys reporting higher in this dimension $[F(1,108)=2538$, $\mathrm{p}=0.034]$.

When comparing the 14 students whose mothers had no studies with the 18 students whose mothers had a higher educational level, significant differences were found (Table 3). Psychological well-being was higher in students whose mothers had a higher educational level, and Mood was superior in the ones whose mothers had no studies. 
Table 2 - Differences according to gender

\begin{tabular}{lcccc} 
& Boys & Girls & $F$ & .034 \\
FI. Physical well-being & 3.2 & 2.8 & 2.538 & .834 \\
F2. Psychological well-being & 3.4 & 3.4 & .693 & .241 \\
F3. Mood & 2.8 & 2.7 & .337 & .940 \\
F4. Self-perception & 3.1 & 3 & .516 & .652 \\
F5. Autonomy & 3.9 & 4 & .442 & .565 \\
F6. Relations with parents and family life & 4 & 3.9 & .599 & .588 \\
F7. Financial Resources & 3.6 & 3.7 & .341 & .466 \\
F8. Social support and support from peers & 4 & 4 & .547 & .099 \\
F9. School Environment & 3.8 & 3.6 & .001 \\
F10. Social Acceptance & 2 & 1.8 & \\
\hline
\end{tabular}

Table 3 - Differences according the mother's educational level

\begin{tabular}{lcccc} 
& No studies & High Education & $F$ & .092 \\
FI. Physical well-being & 2.6 & 3 & .02 & .01 \\
F2. Psychological well-being & 3 & 3.4 & 14.44 & .019 \\
F3. Mood & 3.2 & 2.6 & .07 & .06 \\
F4. Self-perception & 3.2 & 3 & .03 & .233 \\
F5. Autonomy & 4.3 & 4.9 & .13 & .257 \\
F6. Relations with parents and family life & 4.1 & 3.9 & .14 & .766 \\
F7. Financial Resources & 4 & 4 & .03 & .248 \\
F8. Social support and support from peers & 4.3 & 3.8 & .39 \\
F9. School Environment & 4 & 1.6 & .314 \\
Fio. Social Acceptance & 1.7 & & .770 \\
\hline
\end{tabular}

It was also our aim to compare students who had less than four years of residence in the host country with those that lived in it for more than four years. However, the result of the $t$ test indicated no statistically significant differences for any of the factors assessed by the KIDSCREEN-52.

\section{Discussion}

Overall, results indicate that immigrant adolescents from both countries seem to have quite satisfactory perceptions about their welfare and health. This result is consistent with the results reported by Berry et al. (2006) and Neto (2009), which indicated that immigrant youth in thirteen different countries were as well adjusted as their non immigrant peers.
Cross-cultural surveys in European countries show differences in quality of life regarding age and gender. Adolescents report worse quality of life than children on the majority of dimensions. In adolescence, boys report significantly higher quality of life on most dimensions (physical, psychological well-being, autonomy, parent relations, social support, and financial resources) than girls. Girls only scored higher on the dimensions related to peers, school environment and bullying/social acceptance (Gaspar et al., 2009; Michel et al., 2009; The European Kidsreen Group, 2006). However, in our study with immigrant youth, no significant differences were found regarding the perception of health and well-being, except in what concerns Physical Well-being, which was reported significantly higher in 
boys. This finding is particularly important if we consider that, according to Neto (2001; 2005), the adolescent's gender seems to be a predictor of life satisfaction and psychological adjustment in young immigrants.

Moreover, the mothers' level of education, usually considered as an indicator of the social status of origin, was significantly associated with mood and psychological well-being. This result does support previous literature (Feliciano, 2005; Sabatier, 2008). More specifically, the educational level of the parents and family wealth (material factors such as computers, leisure, books, etc.) are relevant to predict well-being in adolescence (Von Rueden et al., 2006). This is an important aspect that deserves attention from policy makers and social entrepreneurs, since low socioeconomic status among parents can contribute to poor childhood health outcomes (Perreira and Ornelas, 2011).

It has been suggested in a study conducted with adult immigrants (Semyonov et al., 2003) that the time spent in the host country affects the adjustment process, in the sense that the first years of immigration are associated with a poorer physical and psychological well-being. However, we have found no significant differences between those immigrant adolescents who lived in the host country for less than four years and those who were resident in the host country for more than four years. This result suggests that the initial negative impact on the adaptation process may be more evident in adult subjects than in adolescents. We may hypothesize that the presence and support of parents may contribute to minimize a negative impact of the adjustment process on the children, having thus a buffering effect on them, preventing children from being full participants in the likely initial situation of precariousness.

On the other hand it is possible that the fact that participants in our study attended public schools facilitates their social integration. At this purpose, Walsh (2010) and suggest that social support from teachers appears to play an important protective role in the psychological adjustment of immigrant adolescents.

In what concerns the comparison between young immigrants living in Spain and those living in
Portugal, results indicate, that in both samples the perception of autonomy, relationship with parents, social support and school environment are quite similar. The fact that in both countries the school environment is quite homogeneous, in the sense that, for several years, a reflection concerning the migratory phenomenon has resulted in programs with similar designs and philosophic backgrounds that have been implemented in Portuguese and in Spanish schools, may explain the similarity found between the two samples in school-related issues.

In its turn, Autonomy and Relationships with Parents seem to be the dimensions more related to issues such as parents' ideology about the development and education of their children and also, those that seem to keep consistent despite the change in geography.

Teenage immigrants living in Huelva seem to show a better perception of their physical and psychological well-being, and a more positive mood than those living in the Algarve. By contrast, children living in Portugal have a perception of family financial capacity higher than those in Spain.

It is necessary to bear in mind that these perceptions are not based in objective data and probably indicate less differences in the purchasing power between native families and immigrant families in Portugal than among native families and immigrants in Spain. On the other hand, young immigrants living in Huelva seem to have greater feelings of rejection by peers when compared to those in the Algarve.

Among the limitations of this study, we must refer its non experimental nature and that this was a non longitudinal study, which prevents the establishment of causal relations between family variables studied and the factors identified in KIDSCREEN-52. Another limitation is the fact that the variables were assessed solely from the point of view of the teenager. It would be interesting to conduct longitudinal studies where, in addition to student information, teachers and families are also inquired.

\section{Acknowledgements}

The Portuguese study was partially financed by Fundação para a Ciência e Tecnologia (FCT) of Portugal. 


\section{References}

ALMGREN, G.; MAGARATI, M.; MOGFORD,

L. Examining the influences of gender, race, ethnicity, and social capital on the subjective health of adolescents. Journal of Adolescence, Oxon, v. 32, n. 1, p. 109-133, 2009.

BERMÚDEZ, M. P. et al. Análisis de la conducta sexual de adolescentes autóctonos e inmigrantes latinoamericanos en España. International Journal of Clinical and Health Psychology, Granada, v. 10, n. 1, p. 89-103, 2010.

BERRY, J. W. Acculturation as varieties of adaptation. In: PADILLA, A. (Ed.). Aculturation: theory, models and findings. Boulder: Wesview, 1980. p. 9-25.

BERRY, J. W. et al. (Ed.). Immigrant youth in cultural transition: acculturation, identity, and adaptation across national contexts. Mawah: Lawrence Erlbaum, 2006.

BRINDIS, C. et al. The associations between immigrant status and risk-behavior patterns in Latino adolescents. Journal of Adolescent Health, San Francisco, v. 17, n. 2, p. 99-105, 1995.

CASTRO, Á.; BERMÚDEZ, M. P.; BUELA-CASAL, G. Variables relacionadas con la infección por VIH en adolescentes inmigrantes latinoamericanos: una revisión. Revista Argentina de Clínica Psicológica, CABA, v. 18, n. 3, p. 227-240, 2009.

FELICIANO, C. Does selective migration matter?: explaining ethnic disparities in educational attainment among immigrants' children.

International Migration Review, New York, v. 39, n. 4 , p. $841-871,2005$.

FRY, R. Are immigrant youth faring better in U.S. schools? International Migration Review, New York, v. 41, n. 3, p. 579-6o1, 2007.

FULIGNI, A. J. Social identity, motivation, and well being among adolescents from Asian and Latin American backgrounds. In: CARLO, G.; CROCKETT, N. J.; CARRANZA, M. (Ed.). Health disparities in youth and families: research and applications. New York: Springer Science, 2011. (Nebraska Symposium on Motivation, 57). p. 97120.
FULIGNI, A. J.; HARDWAY, C. Preparing diverse adolescents for the transition to adulthood. The Future of Children, Princeton, v. 14, n. 2, p. 99-120, 2004.

FULIGNI, A. J.; WITKOW, M.; GARCIA, C. Ethnic identity and the academic adjustment of adolescents from Mexican, Chinese, and European backgrounds. Developmental Psychology, Ann Arbor, v. 41, n. 5, p. 799-811, 2005.

GASPAR, T. et al. Health-related quality of life in children and adolescents and associated factors. Journal of Cognitive and Behavioral Psychotherapies, Cluj-Napoca, v. 9, n. 1, p. 33-48, 2009.

HERNANDEZ, D. J.; MACARTNEY, S.;

BLANCHARD, V. L. Children in immigrant families in eight affluent countries: their family, national and international context. Florence: UNICEF Innocenti Research Centre, 2009.

JOHNSON, M. A. The social ecology of acculturation: implications for child welfare services to children of immigrants. Children and Youth Services Review, Los Angeles, v. 29, n. 11, p. 1426-1438, 2007.

KWAK, K. Adolescents and their parents: a review of intergenerational family relations for immigrant and non-immigrant families. Human Development, Berkeley, v. 46, n. 2/3, p. 115-136, 2003.

MARSIGLIA, F. et al. Immigrant advantage?: substance use among Latin American immigrant and native-born youth in Spain. Ethnicity \& Health, Oxfordshire, v. 13, n. 2, p. 149-170, 2008.

MATOS M. G. et al. Qualidade de vida em crianças e adolescentes: projecto europeu kidscreen, relatório português. Lisboa: Projecto Aventura Social \& Saúde: Faculdade de Motricidade Humana, 2006.

MENDOZA, F.; JAVIER, J.; BURGOS, A. Health of children in immigrant families. In: LANSFORD, J.; DEATER-DECKARD, K.; BORNSTEIN, M. (Ed.). Immigrant families in contemporary society. New York: Guilford, 2007. p. 30-50. 
MICHEL, G. et al. Age and gender differences in health-related quality of life of children and adolescents in Europe: a multilevel analysis. Quality of Life Research, New York, v. 18, n. 9, p. 1147-1157, 2009.

NETO, F. Satisfaction with life among adolescents from immigrant families in Portugal. Journal of Youth and Adolescence, New York, v. 30, n. 1, p. 53-67, 2001.

NETO, F. Predictors of mental health among adolescents from immigrant families in Portugal. Journal of Family Psychology, Atlanta, v. 23, n. 3, p. 375-385, 2009.

PANTZER, K. et al. Health related quality of life in immigrants and native school aged adolescents in Spain. The Journal of Epidemiology and Community Health, London, v. 6o, n. 8, p. 694-698, 2006.

PERREIRA, K. M.; ORNELAS, I. J. The physical and psychological well-being of immigrant children.

The Future of Children, Princeton, v. 21, n. 1, p. 195218, 2011.

PHINNEY, J. S.; ONG, A. Ethnic identity development in immigrant families. In: LANSFORD, J.; DEATER-DECKARD, K.; BORNSTEIN M. (Ed.). Immigrant families in contemporary society. New York: Guilford, 2007. p. 51-68.

PHINNEY, J. S.; ONG, A.; MADDEN, T. Cultural values and intergenerational value discrepancies in immigrant and non-immigrant families. Child Development, Malden, v. 71, n. 2, p. 528-539, 2000. PUSSETTI, C. Identidades em crise: imigrantes, emoções e saúde mental em Portugal. Saúde e Sociedade, São Paulo, v. 19, n. 1, p. 94-113, 2010.

RYAN, L. et al. Depression in Irish migrants living in London: a case-control study. The British Journal of Psychiatry, London, v. 188, p. 560-566, June 2006.
SABATIER, C. Ethnic and national identity among second-generation immigrant adolescents in France: the role of social context and family. Journal of Adolescence, Oxon, v. 31, n. 2, p.185-205, 2008.

SEMYONOV, M.; EPSTEIN, N.; DAVIDOV, E. Period and duration effects on the value of housing among immigrants. Social Science Research, Orlando, v. 32, n. 1, p. 2-24, 2003.

THE EUROPEAN KIDSCREEN GROUPE. The KIDSCREEN questionaires. Lengerich: Pabst Science, 2006.

VEDDER, P.; VAN GEEL, M. Immigrant youth and discrimination. In: GARCIA, C. C. (Ed.). The impact of immigration on children's development. Basel: Karger, 2012. p. 99-121.

VIENO, A. et al. Health status in immigrants and native early adolescents in Italy. Journal of Community Health, New York, v. 34, n. 3, p. 181187, 2009.

VON RUEDEN, U. et al. Socioeconomic determinants of health related quality of life in childhood and adolescence: results from a european study. The Journal of Epidemiology and Community Health, London, v. 6o, n. 2, p. 130-135, 2006.

WALSH, S. D.; HAREL-FISCH, Y.; FOGELGRINVALD, H. Parents, teachers and peer relations as predictors of risk behaviors and mental well-being among immigrant and Israeli born adolescents. Social Science \& Medicine, Boston, v. 70, n. 7, p. 976-984, 2010.

WALSH, S. D. et al. The impact of immigration on the internal processes and developmental tasks of emerging adulthood. Journal of Youth and Adolescence, New York, v. 34, n. 5, p. 413-426, 2005. 